\title{
Concept Attribute
}

National Cancer Institute

\section{Source}

National Cancer Institute. Concept Attribute. NCI Thesaurus. Code C54176.

Any of the properties, roles, or associations, that define a concept. 